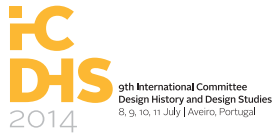

workshop \& roundtable

Blucher Design Proceedings

Dezembro de 2014, Número 5 , Volume 1

Jonathan Woodham

University of Brighton, United Kingdom

\title{
The European Province and Its significance for design histories
}

When the International Conference for the Study of Design History and Design Studies (ICDHS) was first established in Barcelona in 1999 it was devoted to the theme of Historiar desde la periferia: historia e historias del diseño/design history seen from abroad: history and histories of design. This had been one of the growing concerns of an increasing number of researchers outside the dominant Anglophone world of publication and dissemination who sought a more representative delineation of the history of design activity in their own countries and language. As a global language Spanish - the language of Anna Calvera and other colleagues organizing the 1999 Barcelona conference - is spoken by more than 10 times as many people outside Spain than in it; more notably, perhaps in the context of the 2014 conference in Aveiro, Portuguese is spoken by more than 20 times as many people outside Portugal than within it. The fundamental ICDHS position has led to change over the past 15 years, bringing into the wider public domain a wider range design historical research that has previously had no natural home, unsupported by societies and, in some cases, by institutions. Nonetheless, it is still the case that our understanding of design and the history of design does still not encompass such activity in more than a modest percentage of the 200 or so countries in the world, has been dominated by research into the design activities of those belonging to the first industrialised world, and has usually fallen in line with the general preoccupation of design commentators and historians in its concentration on free-market, rather than socialist, economies. As I have sought to convey in several papers and publications over the past decade', analysis of mainstream histories of design and design history readers has shown them to be largely restricted to narratives that embrace between 5 and $10 \%$ of the world's countries.

However, this 2014 ICDHS Round Table discussion is directed at particular questions that seek to address notions of what has been termed the 'European Province' and its 
Table 1.

Percentage of EU population that can speak the language identified in the left hand column significance for design history now and in the future. In the more recent past, when writing about design in countries of the former Eastern European bloc, I attempted to draw attention to the difficulties for research into design and design-related related activities in a number of its constituent countries where access to primary source materials is considerably restricted by the small number of speakers of the language ${ }^{2}$. This has often been exacerbated by a lack of official recognition of the potential importance of design history in terms of its capacity to offer unique cultural, social, economic, political and technological understandings of national identity and change and, as a consequence, has also restricted opportunities for employment in the higher education and museum sectors and for the preservation, organisation and development of archival sources.

To understand the implications of such remarks in relation to Europe, a ranking table of the top ten European languages and the percentage of the EU population that can speak them is revealing. (See Table 1 below).

\begin{tabular}{l|c|}
\hline English & $51 \%$ \\
\hline German & $32 \%$ \\
\hline French & $26 \%$ \\
\hline ttalian & $16 \%$ \\
\hline Spanish & $15 \%$ \\
\hline Polish & $10 \%$ \\
\hline Russian & $7 \%$ \\
\hline Dutch & $6 \%$ \\
\hline Swedish & $3 \%$ \\
\hline Greek & $3 \%$ \\
\hline
\end{tabular}

There are 50 countries that make up Europe, with 28 of them members of the EU (in 2013), with 40 unaccounted for in the table above that have exerted a significant impact on European (and other) culture(s), including the Czech Republic, Denmark, Finland, Hungary and Portugal, with $3 \%$ or less of the EU being able to speak their language. Other countries whose languages can be spoken by only about $1 \%$ of the EU population include Estonia, Latvia and Slovenia.

1 Including 'Local, National and Global: Redrawing the Design Historical Map', Journal of Design History, 18 (3), 2005, pp.257-267; 'The Globalization and Commodification of Design History', Auckland University of Technology, New Zealand, 2005; and 'Design Peripheries, Hidden Histories and the Cartography of Design', in Another Name for Design: Words for Creation, Conference Proceedings, International Conference for Design History and Design Studies, Osaka, Japan, 2008.

2 I have considered the difficulties of linguistic accessibility in a number of recent publications, including 'Post 1945 Industrial Design Perspectives - Slovenia and Iskra in a changing world' in Barbara Predan (ed) ISKRA: 1946-90, Non-Aligned Design, Architecture Museum, Ljubljana, 2010; Chapter 2, 'Design 2012: Where has it come from? What is it? Where is it going?' in Jiri Pelcl, Design: From Idea to Realization, Academy of Arts, Architecture and Design, Prague, pp.11-19; and 'A View from Abroad: IImari Tapiovaara - Design, Myth and Reality in Finland' in Aila Svenskberg (ed), ILMARI TAPIOVAARA: life and Design, Design Museum, Helsinki, 2014 
It is perhaps premature to discuss notions of 'Europe becoming a province in the new world order' when it is still not entirely clear to many what constitute its component parts, particularly given the recent European elections of May 2014, or whether it is conceived as a geographical or political entity (See Table 2). Is the British world constrained by the geographical boundaries of the United Kingdom, the Spanish world by those of Spain, or the Portuguese world by those of Portugal? English is the official language of 83 countries, Spanish the official language of 21 countries, Portuguese of 9 countries, (and France of 40 countries).

\begin{tabular}{|l|}
\hline Albania \\
\hline Andorra \\
\hline Armenia \\
\hline Austria \\
\hline Azerbaijan \\
\hline Belarus \\
\hline Belgium \\
\hline Bosnia \& Herzegovina \\
\hline Bulgaria \\
\hline Croatia \\
\hline Cyprus \\
\hline Czech Republic \\
\hline Denmark \\
\hline Estonia \\
\hline Finland \\
\hline France \\
\hline Georgia \\
\hline
\end{tabular}

\begin{tabular}{l} 
Germany \\
Greece \\
Hungary \\
\hline Celand \\
Ireland \\
Italy \\
Kosovo \\
Latvia \\
Lichtenstein \\
Lithuania \\
Luxembourg \\
Macedonia \\
Malta \\
Moldova \\
Monaco \\
Montenegro \\
Netherlands \\
\hline
\end{tabular}

\begin{tabular}{l|}
\hline Norway \\
Poland \\
\hline Portugal \\
\hline Romania \\
\hline Russia \\
\hline San Marino \\
Serbia \\
\hline Slovakia \\
\hline Spain \\
Sweden \\
Switzerland \\
\hline Turkey \\
\hline Ukraine \\
\hline United Kingdom \\
\hline Vatican \\
\hline
\end{tabular}

Table 2. Countries of Europe (50) Member Countries of the EU in 2013 (28)

In the guidelines provided for the preparation of contributions to this, the Aveiro, Round Table debate, it is also unclear as to what is meant by 'East Asia' given that the economic, social, political and cultural position of countries such as South Korea, Japan, China, India, Thailand, and Vietnam vary considerably, although all have an important place in 21st century design, as well as earlier periods?3. Notions that the term 'East Asia' represents a

3 Some also collaborate: for example, in 2012, the India Design Council entered into a Memorandum of Understanding (MoU) with the Japan Industrial Design Promotion Organization (JIDPO) for collaboration, education and development of design skills in both countries. More significantly, in April 2012 the Prime Ministers of India and Japan, together with their respective Ministers of Commerce and Industry (India) and of Economy, Trade, Industry (Japan) expressed their intention of enhancing the cooperation between their two countries in respect of the Creative Industries which was subsequently delivered through a number of actions. 
collective position - rather than a geographical location - analogous to the characteristics of Victorian Britain's 'Workshop of the World' seem a little historically unsophisticated. What is of fundamental concern is the fact that considerable advances are being made in design thinking and design innovation in a number of East Asian countries ${ }^{4}$. At the core of contemporary design debate lie concerns about the continuing global pre-eminence of design expertise in a number of European countries and not simply the fact that shifts in global economic power will see the emergence of Brazil, Russia, India and China as world economic powers. The potential battlegrounds for design leadership are more likely to be located in global 'hot spots' where excellence in design thinking, innovation and the capacity for imaginative solutions to complex problems are in the ascendancy. Several European countries are seeking to retain their 'hot spot' status.

Even were it the case that Europe, the second smallest continent after Australia, was considered by some to be a province in the light of shifts in global design activity and economic power, it does not follow that this would be the case in terms of design history. The strength of the ICDHS position, for instance, is that it has sought to be inclusive, unconstrained by national boundaries and committed to considerations of 'design history seen from abroad: history and histories of design'. The Design History Society, established in Brighton in 1977 and based in Britain, has become more visibly outward facing, as evidenced by a comparative analysis of the geographical spread of articles in the first ten years of its Journal of Design History and those of the last ten years prior to March $2014^{5}$, as well as the more recent initiative of mounting its annual conferences outside the UK. As British design historian Penny Sparke wrote in her obituary of pioneering design historian John Heskett (1937-2014) in the Guardian newspaper:

....as [in the later 1970 s and 1980s] design became a global concept increasingly valued by corporations and governments alike, design history became, along with design pedagogy, one of the nation's [Britain's] most successful academic exports. John brought his deep knowledge of economics, politics and history to the project and worked alongside scholars from other disciplines to understand and communicate the meaning and function of that increasingly important concept, "design", both past and present. ${ }^{6}$

However, given the emphasis on Europe laid down for the Aveiro Round Table discussion it is perhaps pertinent to suggest that, despite its considerable achievements in countering the Anglophone dominance of design history publication and dissemination,

\footnotetext{
${ }^{4}$ The Cox Review of Creativity in Business (2005), commissioned by the Chancellor of the Exchequer Gordon Brown wrongly came to the conclusion that the future economic powerhouses of Brazil, Russia, India and China (the BRIC economies) would not emerge fully for many years, thereby giving the UK creative industries a significant window to establish themselves as a global leaders in the field. In reality the timeframe has proved to be much shorter.

5 / considered a number of comparative global mapping perspectives in my keynote on 'Redesigning Design History in the 215t Century' at the Doctoral Design Festival at the Politecnico di Milano in March 2014 .

${ }^{6}$ Penny Sparke, 'John Heskett (1937-2014), The Guardian, 12 March 2014.
} 
the 15 year old perspective of the ICDHS still remains comparatively modest in terms of global spread of national contributions to its conferences (perhaps representing up to $25 \%$ of globally recognised countries). Perhaps surprisingly, our understanding and knowledge of European design histories is still comparatively limited in terms of the full range of countries located in the region, as seen in those listed in Table 2 (above), for some of the reasons I have suggested. Historiar desde la periferia: historia e historias del diseño/design history seen from abroad: history and histories of design, the maxim of the inaugural ICDHS event in Barcelona in 1999, still has powerful considerations for the construction of a meaningful European as well as global history of design.

There is much to be done. 
